\title{
Rancang Bangun E-Learning System Pada SMK Pratiwi Prabumulih Menggunakan PHP \& MySQL
}

\author{
Juliansyah, Khana Wijaya \& Muchlis \\ Sekolah Tinggi Manajemen Informatika Dan Komputer Prabumulih
}

\begin{abstract}
Along with the development of internet technology, e-learning began to be developed. Thus encouraging the authors to maintain the quality of education by applying e-learning at Pratiwi Prabumulih Vocational High School. E-learning is one of the tools to improve the efficiency and effectiveness of performance in the teaching and learning process. E-learning is a web-based system developed using the PHP programming language, HTML document types and MySQL to manage databases. The research method used is the system development method, namely the waterfall method. The system design method with a functional approach is described using UML (Unified Modeling Language). With the web-based e-learning system, the teaching and learning process can be accessed in all places anytime and anywhere without time restrictions. E-learning supports functions/features (upload and download) of data in the form of document content. E-learning is also able to display online questions or exams and score results so that it helps in the learning process
\end{abstract}

Keywords: Sistem Pembelajaran Electronic- Elearning System.

\section{Pendahuluan}

Perkembangan teknologi sudah banyak memberi pengaruh terhadap cara hidup kita, salah satunya adalah dalam bidang pendidikan dengan penggunaan e-learning dalam kegiatan pembelajaran di Sekolah, tempat kursus dan lain lain sudah mulai menggunakan konsep seperti ini.

Sekolah Menengah Kejuruan Pratiwi Prabumulih hendaknya dapat memberikan pelayanan terbaik kepada Siswa untuk menyerap materi-materi pembelajaran yang diberikan oleh Guru. Pentingnya memanfaatkan teknologi merupakan tantangan bagi sebuah Sekolah untuk mampu menunjang media pembelajaran yang sudah ada untuk digantikan dengan media pembelajaran yang lebih menarik. Untuk mengimplementasikan hal tersebut, salah satu sarana yang dapat dikembangkan adalah dengan membangun sistem informasi berbasis teknologi yaitu mengembangkan $e$ learning berbasis web. Peneliti memilih

e-learning berbasis web karena dengan kegiatan pembelajaran e-learning dimungkinkan berkembangnya fleksibelitas belajar Siswa yang optimal, Siswa dapat mengakses bahanbahan belajar maupun materi pelajaran setiap saat, kapanpun dan dimanapun serta berulang ulang asal tersedianya koneksi jaringan internet.

Melalui e-learning Guru juga dapat membagikan materi pelajaran secara daring. Melakukan quiz dan ujian serta bagi Sekolah akan tersedia bahan ajar yang telah divalidasi sesuai dengan bidangnya sehingga setiap Guru dapat menggunakan dengan mudah serta efektivitas dan efesiensi pembelajaran di Sekolah secara keseluruhan mutunya akan meningkat.

Dari beberapa Penjelasan diatas dapat disimpulkan bahwa, pengembangan e-learning 
berbasis web, mempunyai pengaruh yang positif terhadap proses pembelajaran dikelas. e-learning berbasis web ini dinilai sangat tepat, karena untuk fasiltas internet di sekitar sekolah sudah banyak dan semuanya free wifi, serta belum diterapkan nya media $e$ learning oleh Guru ketika melakukan pembelajaran. Hal ini yang membuat peneliti tertarik untuk meneliti dan mengembangkan elearning berbasis web yang dapat digunakan oleh Siswa sebagai media pembelajaran yang efektif dan efesien.

Dengan demikian, seperti yang telah dipaparkan oleh penulis sebelumnya, terkait pentingnya media pembelajaran e-learning berbasis web sebagai sarana mempermudah Siswa dalam poses pembelajaran. Maka, untuk menjawab kebutuhan tersebut penulis akan melakukan penelitian yang berjudul : "Rancang bangun E-learning System pada SMK Pratiwi Prabumulih menggunakan PHP \& MySQL"

\section{Tinjauan Literatur}

\subsection{Pengertian Rancang Bangun}

Rancang bangun adalah suatu istilah umum untuk membuat atau mendesain suatu objek dari awal pembuatan sampai akhir pembuatan. (Imam, D : 2016)

\subsection{Pengertian Sistem}

Menurut Tata Sutabri (2016:7) sistem adalah sekelompok unsur yang erat hubungannya satu dengan yang lain, yang berfungsi bersama-sama untuk mencapai tujuan tertentu.

Menurut Heny Pratiwi (2016:4) sistem adalah kumpulan dari obyek-obyek seperti orang, resources, konsep dan prosedur yang ditujukan untuk melakukan fungsi tertentu untuk memenuhi suatu tujuan.

\subsection{Pengertian E-learning}

E-learning adalah Pembelajaran yang disusun ialah dengan tujuan menggunakan suatu sistem elektronik atau juga komputer sehingga mampu untuk mendukung suatu proses pembelajaran . (Michael, 2013:27)

E-learning adalah Suatu proses pembelajaran jarak jauh dengan cara menggabungkan prinsip-prinsip didalam proses suatu pembelajaran dengan teknologi . (Candarawati : 2010)

\subsection{E-learning berbasis web}

E-learning yang berbasis web atau biasa disebut dengan web based learning (WBL) merupakan salah satu bentuk pemanfaatan teknologi informasi dalam dunia pendidikan. Menurut Simamora (Made Wena, 2010: 215), WBL merupakan suatu sistem atau proses untuk melaksanakan kegiatan belajar mengajar jarak jauh melalui aplikasi web dan jaringan internet, artinya media e-learning yang dikembangkan berisi sebuah sistem pembelajaran yang lebih memanfaatkan aplikasi web yang didukung dengan koneksi jaringan internet.

\subsection{Pengertian Web}

Website adalah suatu media publikasi elektronik yang terdiri dari halaman halaman web (web page) yang terhubung satu dengan yang lain menggunakan link yang dilekatkan pada suatu teks atau image. Website dibuat pertama kali oleh Tim Barners Lee pada tahun 1990. Website dibangun dengan menggunakan bahasa Hypertext Markup Language 
(HTML) dan memanfaatkan protokol komunikasi Hypertext Transfer Protocol (HTTP) yang terletak pada application layer pada referensi layer OSI.

\subsection{Unified Modeling Language (UML)}

$U M L$ adalah salah satu standar bahasa yang banyak digunakan di dunia industri untuk mendefinisikan requirement, membuat analisis dan desain, serta menggambarkan arsitektur dalam pemrograman berorientasi objek dengan kata lain $U M L$ berarti bahasa pemodelan standar dan merupakan alat komunikasi yang konsisten dalam mendukung para pengembang saat ini.

\subsection{Pengertian MySQL}

Menurut Abdul Kadir (2013:15) MySQL adalah nama database server. Database server adalah server yang berfungsi untuk menangani database. Database adalah suatu pengorganisasian data dengan tujuan memudahkan penyimpanan dan pengaksesan data.

\subsection{Pengertian Xampp}

Menurut Edi Winarno dkk (2014:1) xampp adalah software web server yang bisa dipakai untuk mengakomodasi sistem operasi yang anda pakai (X), Apache (A), MySQL (M), PHP $(P)$, dan $\operatorname{Perl}(P)$.

\section{Metode Penelitian}

\subsection{Objek Penelitian}

Objek penelitian pada penyusunan Skripsi ini adalah Sekolah Menengah Kejuruan Pratiwi Prabumulih yang beralamat di Jalan Mayor Iskandar No. 3455 Mangga Besar Kecamatan Prabumulih Utara Kota Prabumulih.

\subsection{Metode Penelitian}

Dalam penelitian ini penulis menggunakan metode penelitian deskriptif, Metode deskriptif merupakan suatu metode penelitian dalam meneliti status dari sekelompok manusia, suatu obyek, suatu sistem pemikiran, suatu set kondisi, ataupun suatu kelas peristiwa pada masa saat ini. adapun tujuan dari penelitian deskriptif ini yaitu untuk membuat gambaran, deskipsi atau lukisan secara sistematis, faktual dan akurat mengenai fakta, sifat serta hubungan antar fenomena yang sedang diteliti. Menurut Hidayat (2010), penelitian deskriptif merupakan metode penelitian yang digunakan untuk menemukan pengetahuan yang seluas luasnya terhadap objek penelitian pada suatu masa tertentu. Sedangkan menurut Punaji (2010) penelitian deskriptif adalah penelitian yang tujuannya untuk menjelaskan atau mendeskripsikan suatu peristiwa, keadaan, objek apakah orang, atau segala sesuatu yang terkait dengan variabel-variebel yang bisa dijelaskan baik menggunakan angka-angka maupun kata-kata.

\subsection{Metode Pendekatan dan Pengembangan Sistem}

\subsubsection{Metode Pendekatan Sistem}

Metode pendekatan yang digunakan adalah pendekatan terstruktur, metode pendekatan terstruktur adalah suatu proses untuk mengimplementasikan urutan langkah untuk menyelesaikan suatu masalah dalam bentuk program. Penulis memilih pendekatan terstruktur karena penyusunan laporan akan didasarkan pada data data yang diperoleh dari 
objek penelitian yaitu SMK Pratiwi Prabumulih. Dan penyelesaiannya dalam bentuk program aplikasi.

\subsubsection{Metode Pengembangan Sistem}

Metode pengembangan yang penulis gunakan adalah metode waterfall. Metode air terjun atau yang sering disebut metode waterfall sering dinamakan siklus hidup klasik (classic life cycle), dimana hal ini menggambarkan pendekatan yang sistematis dan juga berurutan pada pengembangan perangkat lunak, dimulai dengan spesifikasi kebutuhan pengguna lalu berlanjut melalui tahapan-tahapan perencanaan (planning), permodelan (modeling), konstruksi (construction), serta penyerahan sistem ke para pelanggan/pengguna (deployment), yang diakhiri dengan dukungan pada perangkat lunak lengkap yang dihasilkan (Pressman, 2012). Tahapan metode waterfall dapat dilihat pada gambar di bawah ini.

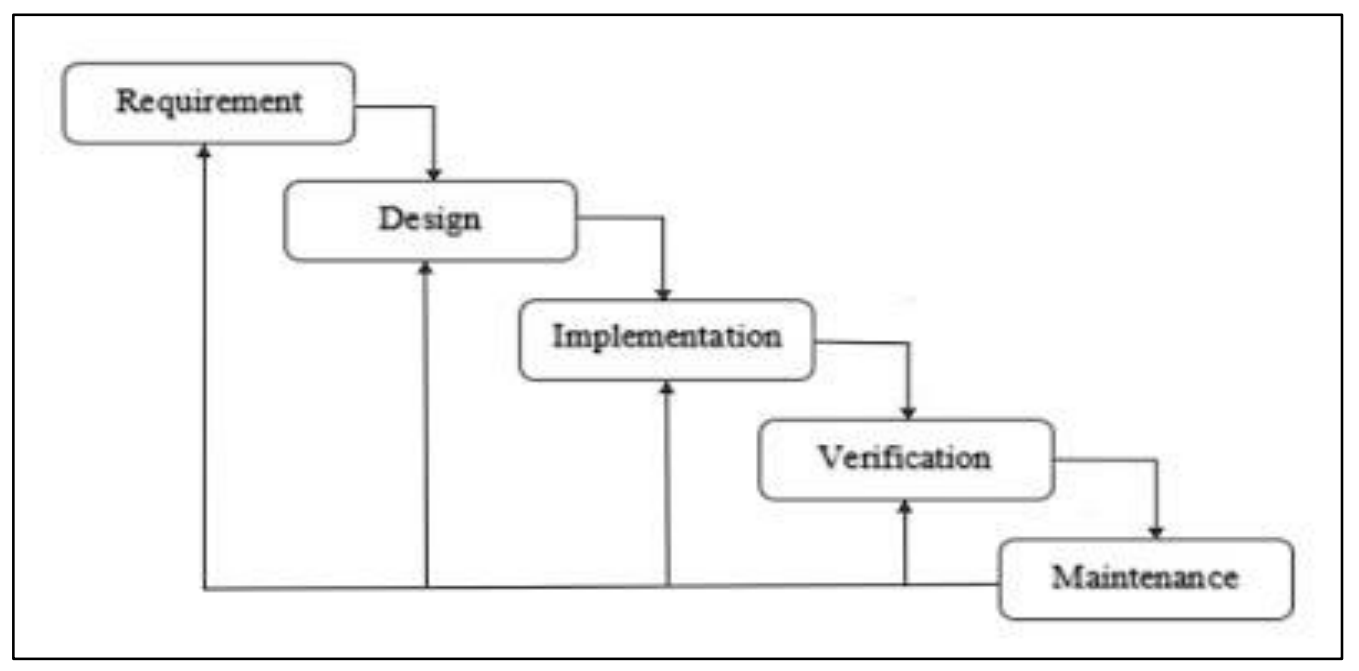

Gambar 3.1 Metode waterfall (Pressman :2012)

Dalam pengembangannya metode waterfall memiliki beberapa tahapan yang berurut yaitu: requirement (analisis kebutuhan), design system (desain sistem), Coding (pengkodean) \& Testing (pengujian), Penerapan Program, pemeliharaan. Tahapan tahapan dari metode waterfall adalah sebagai berikut :

\section{Requirement Analisis}

Tahap ini pengembang sistem diperlukan komunikasi yang bertujuan untuk memahami perangkat lunak yang diharapkan oleh pengguna dan batasan perangkat lunak tersebut. Informasi ini biasanya dapat diperoleh melalui wawancara, diskusi atau survei langsung. Informasi dianalisis untuk mendapatkan data yang dibutuhkan oleh pengguna.

\section{System Design}

Spesifikasi kebutuhan dari tahap sebelumnya akan dipelajari dalam fase ini dan desain sistem disiapkan. Desain Sistem membantu dalam menentukan perangkat keras(hardware) dan sistem persyaratan dan juga membantu dalam mendefinisikan arsitektur sistem secara keseluruhan.

\section{Implementation}

Pada tahap ini, sistem pertama kali dikembangkan di program kecil yang disebut unit, 
yang terintegrasi dalam tahap selanjutnya. Setiap unit dikembangkan dan diuji untuk fungsionalitas yang disebut sebagai unit testing.

\section{Integration \& Testing}

Seluruh unit yang dikembangkan dalam tahap implementasi diintegrasikan ke dalam sistem setelah pengujian yang dilakukan masing-masing unit. Setelah integrasi seluruh sistem diuji untuk mengecek setiap kegagalan maupun kesalahan.

\section{Operation \& Maintenance}

Tahap akhir dalam model waterfall. Perangkat lunak yang sudah jadi, dijalankan serta dilakukan pemeliharaan. Pemeliharaan termasuk dalam memperbaiki kesalahan yang tidak ditemukan pada langkah sebelumnya. Perbaikan implementasi unit sistem dan peningkatan jasa sistem sebagai kebutuhan baru.

\subsection{Alat Bantu Analisis dan Perencangan}

\subsubsection{UML (Unified Modeling Language)}

Menurut Rosa dan Shalahuddin (2014:26) UML merupakan standar bahasa yang banyak digunakan didunia industri untuk mendefinisikan requirement, membuat analisis dan desain, serta menggambarkan arsitektur dalam pemrograman berorientasi objek.

\section{Use Case Diagram}

Menurut Rosa dan Shalahudin (2014:55) use case diagram mendeskripsikan sebuah interaksi antara satu atau lebih actor dengan sistem informasi yang akan dibuat dan juga untuk mengetahui fungsi apa saja yang ada di dalam sebuah sistem informasi serta siapa saja yang berhak menggunakan fungsi-fungsi itu. Berikut ini adalah simbol-simbol yang ada pada use case diagram:

Tabel 3.1 simbol use case diagram

\begin{tabular}{|l|l|l|l|}
\hline No & Gambar & Nama & Uraian \\
\hline 1. & Actor & $\begin{array}{l}\text { Mempesifikasi himpunan peran yang } \\
\text { pengguna mainkan ketika berinteraksi } \\
\text { dengan use case }\end{array}$ \\
\hline 2. & Depedency & $\begin{array}{l}\text { Hubungan dimana perubahan yang } \\
\text { terjadi pada suatu elemen mandiri akan } \\
\text { pada elemen yang tidak mandiri }\end{array}$ \\
\hline 3. & $+\ldots->$ & Generalication & $\begin{array}{l}\text { Hubungan dimana objek anak } \\
\text { (descendent) berbagai perilaku dan } \\
\text { struktur data dari objek yang ada } \\
\text { diatasnya objek induk (ancestor) }\end{array}$ \\
\hline 4. & $-\ldots \ldots+-$ & Include & $\begin{array}{l}\text { Menspesifikasikan bahwa use case } \\
\text { sumber secara eksplisit }\end{array}$ \\
\hline
\end{tabular}




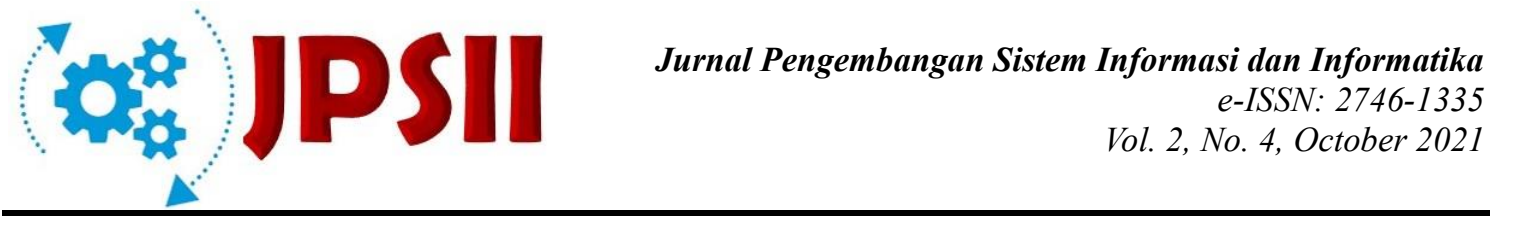

\begin{tabular}{|l|l|l|l|}
\hline 5. & $\leftarrow$ & Extend & $\begin{array}{l}\text { Mendeskripsikan bahwa use case } \\
\text { memperluas perilaku dari use case } \\
\text { sumber-sumber pada suatu titik yang } \\
\text { diberikan }\end{array}$ \\
\hline 6. & -5 Asociation & $\begin{array}{l}\text { Apa yang menghubungkan dari objek } \\
\text { satu ke objek lainnya }\end{array}$ \\
\hline 8. & System & $\begin{array}{l}\text { Menspesifikasikan paket yang } \\
\text { menampilkan suatu sistem terbatas }\end{array}$ \\
\hline 9. & Use Case & $\begin{array}{l}\text { Deskripsi dari urutan aksi-aksi yang } \\
\text { ditampilkan dari suatu hasil yang terukur } \\
\text { bagi suatu actor }\end{array}$ \\
\hline 10. & Collaboration & $\begin{array}{l}\text { Interaksi antara elemen lain yang bekerja } \\
\text { sama untuk menyediakan perilaku yang } \\
\text { lebih besar dari jumlah dan elemen- } \\
\text { elemennya (sinergi) }\end{array}$ \\
\hline
\end{tabular}

\section{Activity Diagram}

Menggambarkan work flow (aliran kerja) atau aktivitas dari sebuah sistem atau proses bisnis yang ada pada perangkat lunak dan juga menggambarkan aktivitas sistem bukan apa yang dilakukan actor, jadi aktivitas yang dapat dilakukan oleh sistem. Berikut ini adalah simbol dari activity diagram:

Tabel 3.2 simbol activity diagram

\begin{tabular}{|c|c|}
\hline Simbol & Deskripsi \\
\hline Status awal & $\begin{array}{l}\text { Status awal aktivitas sistem, sebuah diagram } \\
\text { aktivitas memiliki sebuah status awal }\end{array}$ \\
\hline Aktivitas & $\begin{array}{l}\text { Aktivitas yang dilakukan sistem, biasanya diawali } \\
\text { dengan kata kerja }\end{array}$ \\
\hline Percabangan/decistion & $\begin{array}{l}\text { Asosiasi percabangan dimana jika ada pilihan } \\
\text { aktivitas lebih dari satu }\end{array}$ \\
\hline Penggabungan/ join & $\begin{array}{l}\text { Asosiasi penggabungan dimana lebih dari satu } \\
\text { aktivitas digabungkan menjadi satu }\end{array}$ \\
\hline
\end{tabular}


Status akhir

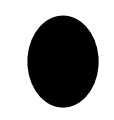

Status akhir yang dilakukan sistem, sebuah diagram aktivitas memiliki sebab status akhir Memisahkan organisasi bisnis yang bertanggung jawab terhadap aktivitas yang terjadi

\section{Class Diagram}

Class diagram adalah model statis yang menggambarkan struktur dan deskripsi class serta hubungannya antar class. Menggambarkan struktur sistem dari segi pendefinisian kelas-kelas yang akan dibuat untuk membangun sistem. Dalam diagram class memiliki atribut dan metode atau operasi. Berikut ini merupakan simbol-simbol yang ada pada class diagram.

Tabel 3.3 simbol class diagram

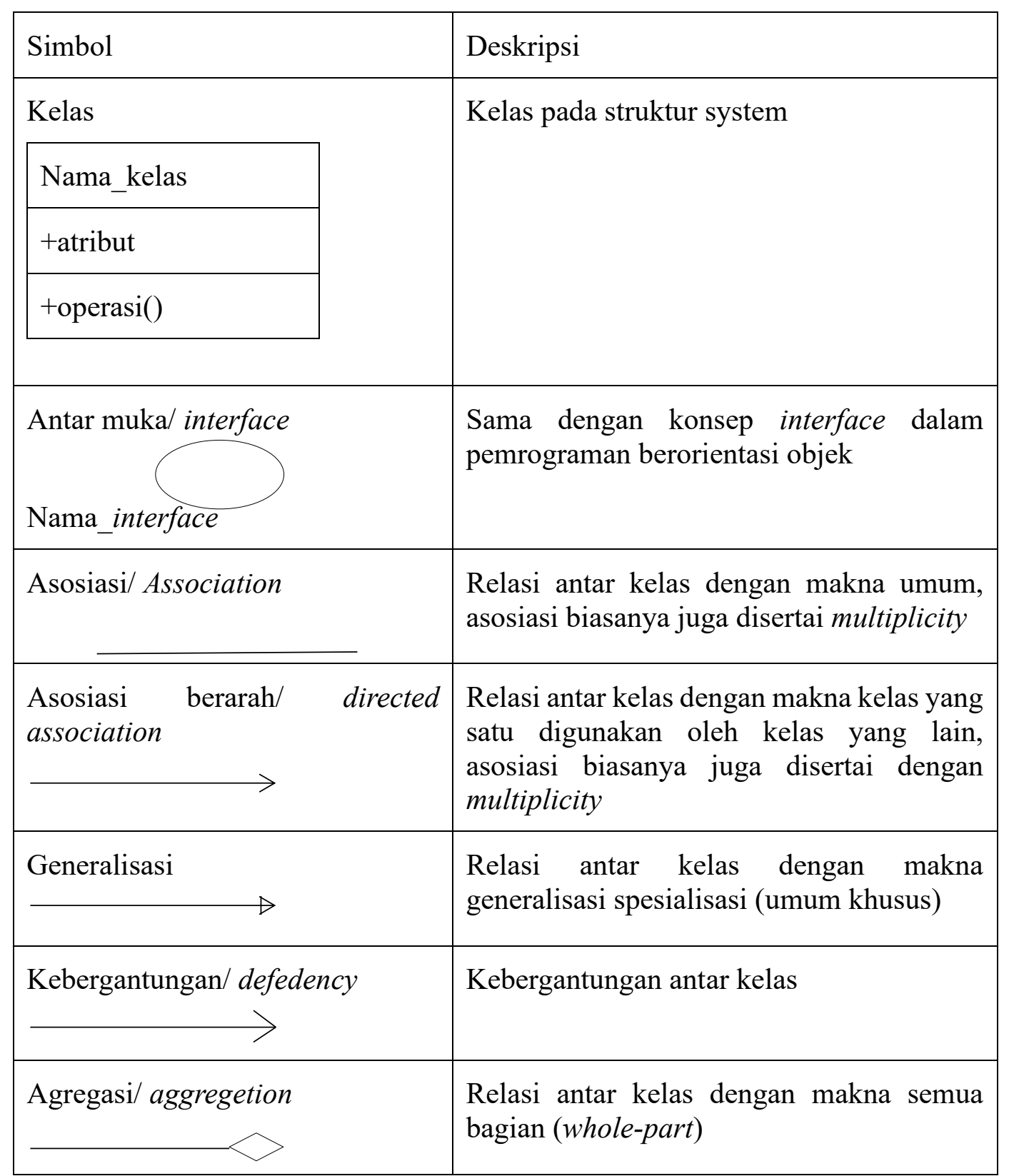




\subsection{Pengujian Software}

Metode pengujian yang dipakai pada penelitian penulis ini adalah metode pengujian langsung yaitu dengan menggunakan pengujian Black Box. Digunakan untuk menguji fungsi-fungsi dan fitur yang di rancang dalam perangkat lunak prototype. Kebenaran perangkat lunak yang diuji hanya dilihat berdasarkan output yang dihasilkan dari data atau perintah yang diinput untuk fungsi yang ada tanpa melihat bagaimana proses untuk mendapatkan hasil output tersebut.

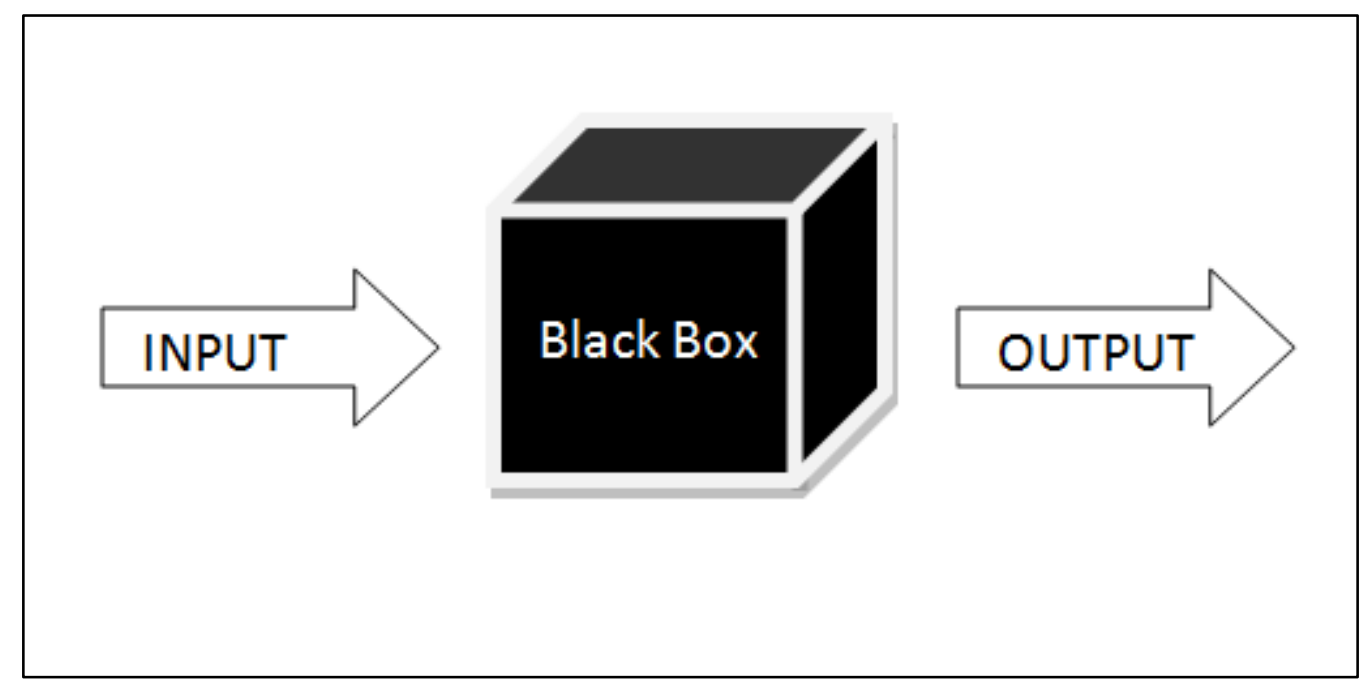

Gambar 3.3 Pengujian Black Box

\section{Hasil dan Pembahasan}

\subsection{Implementasi}

Tahap Implementasi merupakan tahap penerapan sistem supaya dapat dioperasikan. Pada tahap ini dijelaskan mengenai implementasi perangkat lunak. Implementasi perangkat keras, implementasi antar muka E-learning System SMK Pratiwi Prabumulih

\subsubsection{Implementasi Perangkat Lunak}

Untuk mendukung sistem yang diusulkan berjalan dengan optimal, dibutuhkan software pengolahan data, adapun perangkat lunak yang digunakan untuk mendukung pembuatan program aplikasi ini sebagai berikut :

1. Sistem Operasi Windows 10

2. Adobe Photoshop

3. Adobe Dreamweaver

4. Xampp Control Panel (server local)

\subsubsection{Implementasi Perangkat Keras}

Perangkat keras yaitu peralatan dalam bentuk fisik yang menjalankan komputer. hardware dapat digunakan sebagai media untuk menjalankan perangkat lunak dan peralatan ini berfungsi untuk menjalankan instruksi-instruksi yang diberikan dan mengeluarkan dalam bentuk informasi yang digunakan oleh manusia untuk laporan. Adapun perangkat keras yang digunakan untuk mendukung pembuatan program ini sebagai berikut : 
1. Laptop

2. Processor Intel Core $i 3$ atau diatasnya

3. Hardisk $320 G B$ atau diatasnya

4. RAM $4 G B$

5. VGA $512 \mathrm{MB}$

\subsection{Pembahasan}

Penelitian ini membahas mengenai bagaimana penerpan sistem pembelajaran online berbasis web dalam mempermudah guru dan siswa dalam melakukan aktivitas belajar dan mengajar. Bagaimana landasan teori pada bab sebelumnya bagaimana merancang bangun E-learning System pada SMK Pratiwi Prabumulih tersebut.

\subsection{Implementasi Database}

Implementasi database untuk aplikasi sistem informasi e-learning pada SMK Pratiwi Prabumulih menggunakan bantuan web server dari Xampp dengan mengaktifkan Apache dan MySQL. Untuk mengakses database dilakukan pada browser mozilla yaitu dengan mengetikkan http://localhost/phpmyadmin

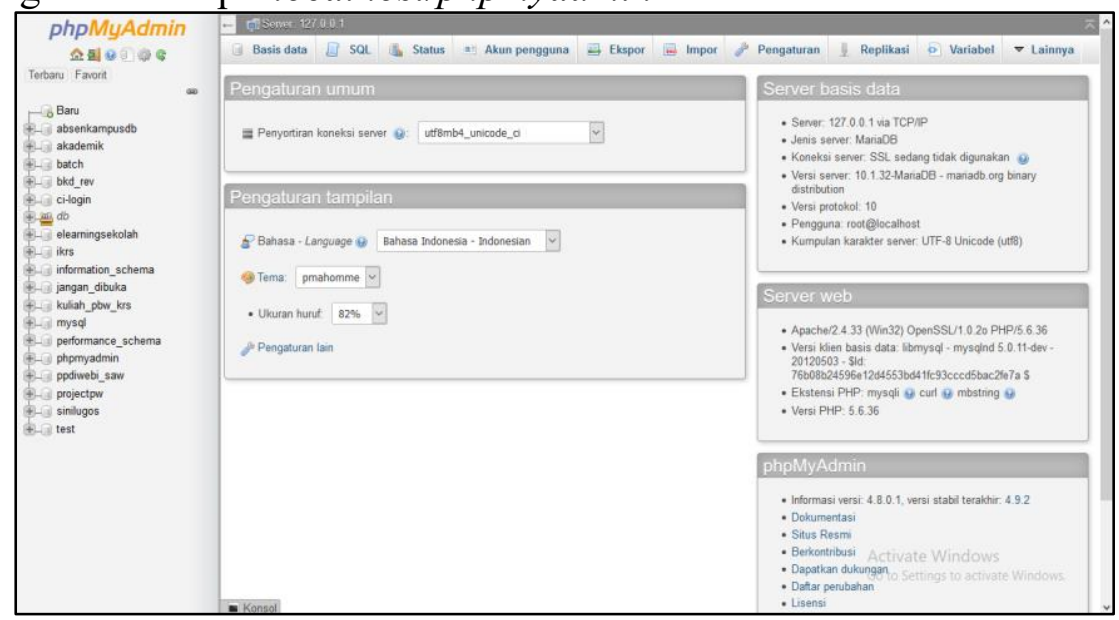

Gambar 4. 1 PhpMyAdmin

Pada halaman utama phpmyadmin ditampilkan beberapa database yang akan digunakan dalam penyimpanan data untuk sistem informasi e-learning.

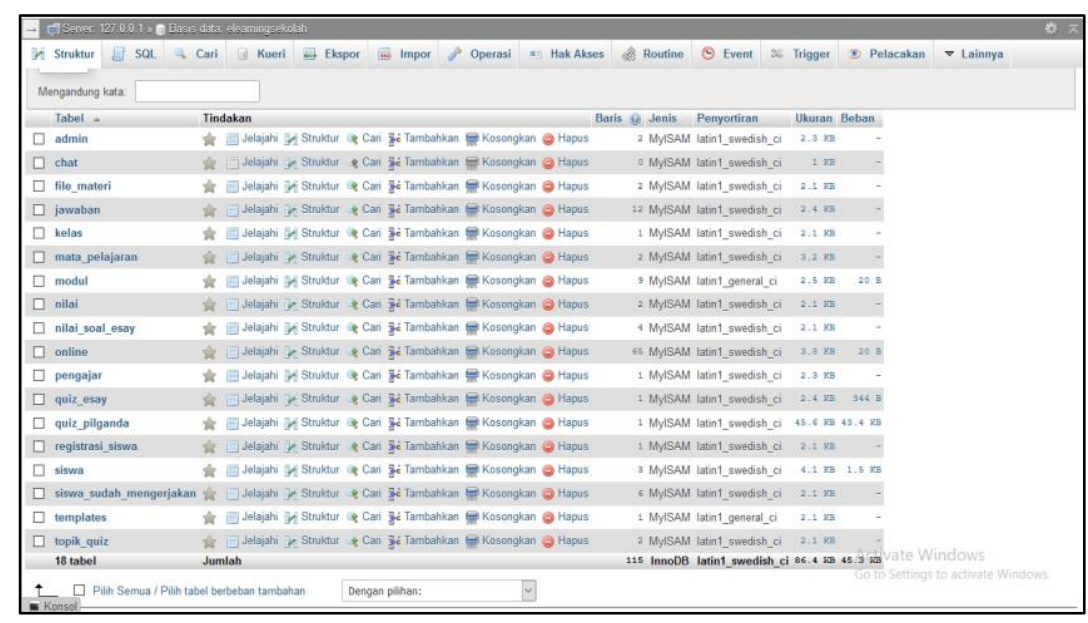

Gambar 4.2 Tabel Database

Published by: 


\subsection{Implementasi Antar Muka}

Implementasi antar muka dilakukan dengan membuat antar muka pada form yang ada pada website ini. Setiap halaman yang akan dibuat akan dibentuk sebuah file yang berektensi $p h p$. File-file tersebut selanjutnya dapat diakses dan akan menjadi penghubung antara admin, guru dan siswa dengan website ini, pada implementasi antar muka halaman utama merupakan sentral penghubung dengan antar muka yang lain. Berikut adalah implementasi antara muka website e-learning System SMK Pratiwi Prabumulih:

1. Tampilan Halaman Login Admin \& Guru

Menampilkan halaman login, admin \& Guru harus login untuk masuk ke halaman interface admin atau Guru.

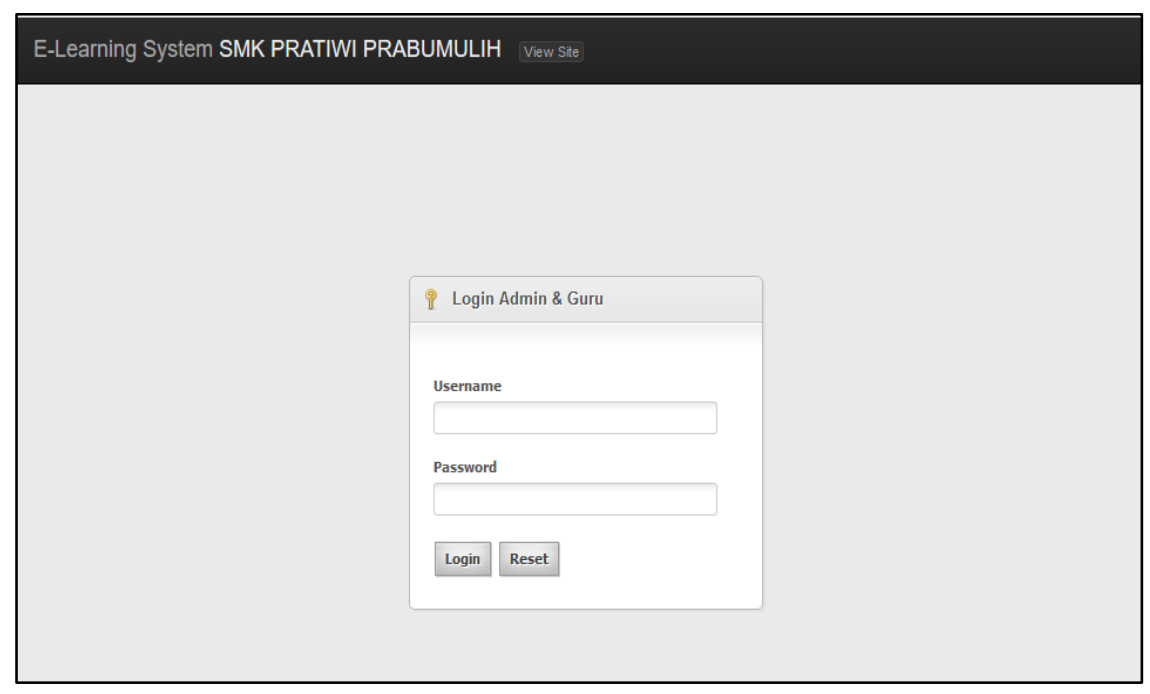

Gambar 4.3 Halaman Login Admin \& Guru

2. Tampilan Halaman Home Admin

Setelah admin login maka selanjutnya akan tampil halaman home yang berisikan menu-menu yang terdiri dari halaman manajemen modul, manajemen Guru, manajemen Siswa, manajemen kelas, manajemen pelajaran, manajemen materi, manajemen tugas/quiz dan registrasi Siswa.

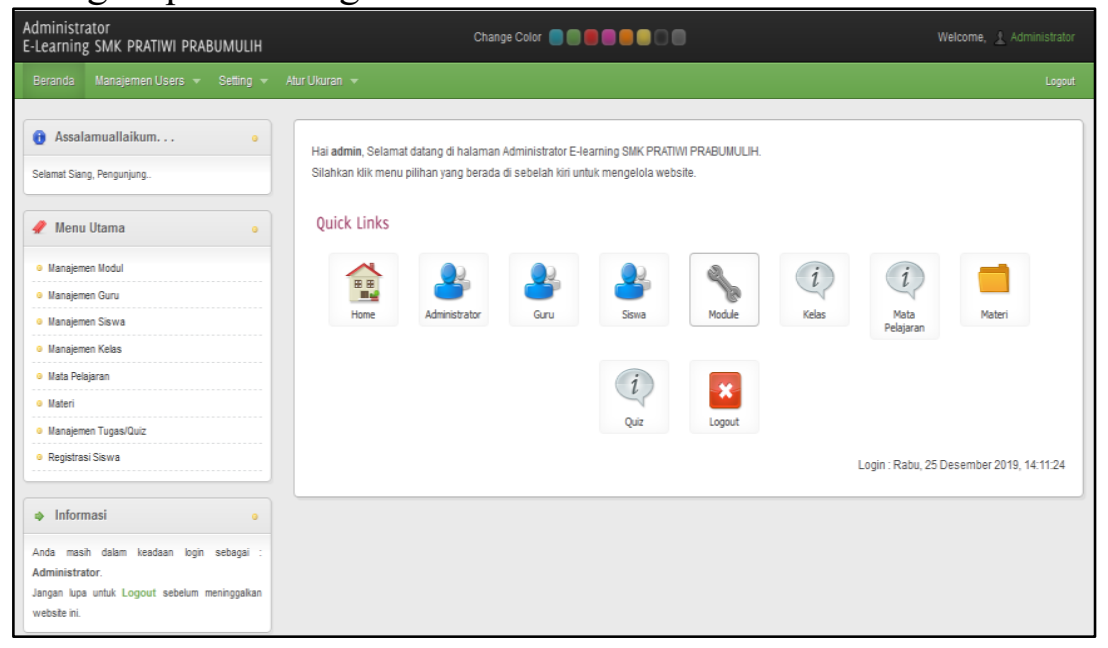

Gambar 4.4 Halaman Home Admin 
3. Tampilan Halaman Login Siswa

Menampilkan halaman login, Siswa harus login untuk masuk ke halaman interface portal e-learning.

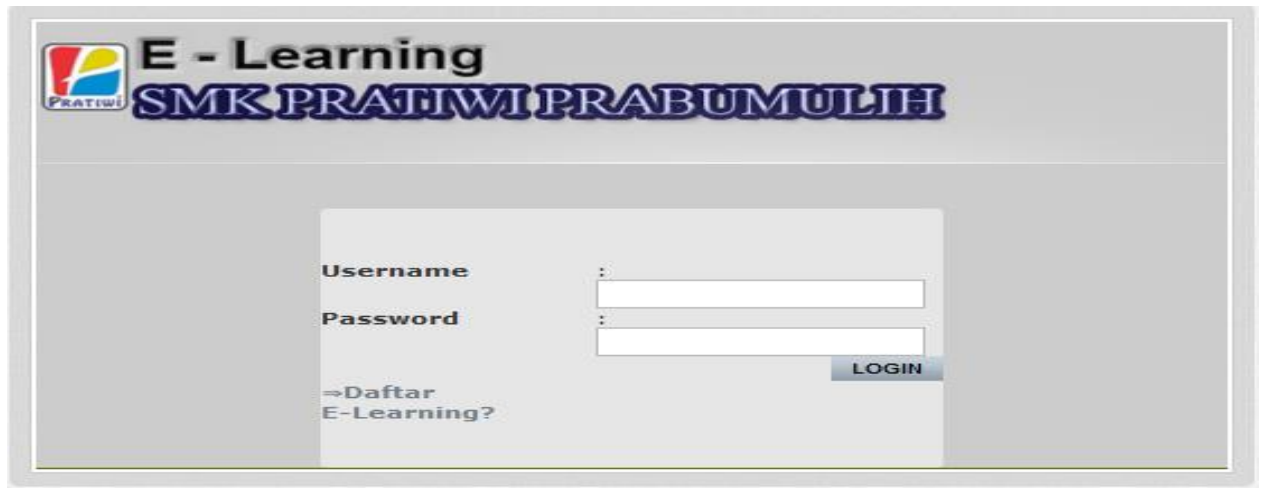

\section{Gambar 4.5 Halaman Login Siswa}

4. Tampilan Halaman Home Siswa

Setelah Siswa login maka selanjutnya akan tampil halaman home yang berisikan menu-menu yang terdiri dari halaman kelas yang diikuti, Mata pelajaran yang diikuti, materi yang dibagikan, serta mengerjakan tugas dan quiz yang diberikan guru. Berikut adalah tampilan antar muka home Siswa.

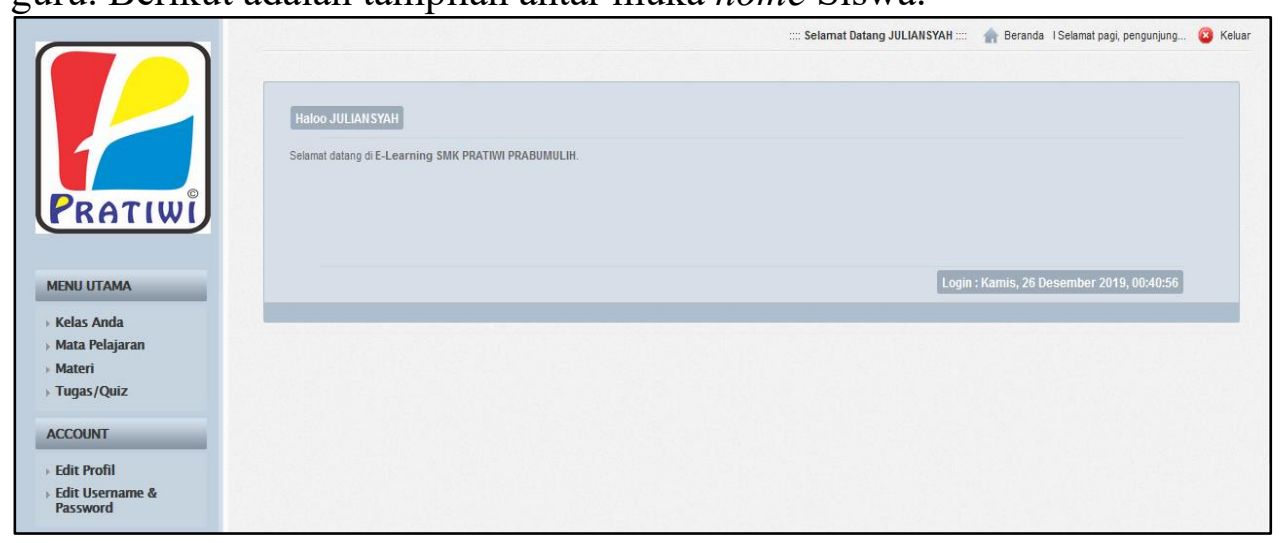

Gambar 4.6 Halaman Antar Muka Siswa

5. Tampilan Halaman Manajemen Modul

Pada halaman manajemen modul ini merupakan halaman untuk mengatur, menampilkan, menghapus, mengedit serta mengurutkan menu utama yang ada pada website. Berikut tampilan manajemen modul: 


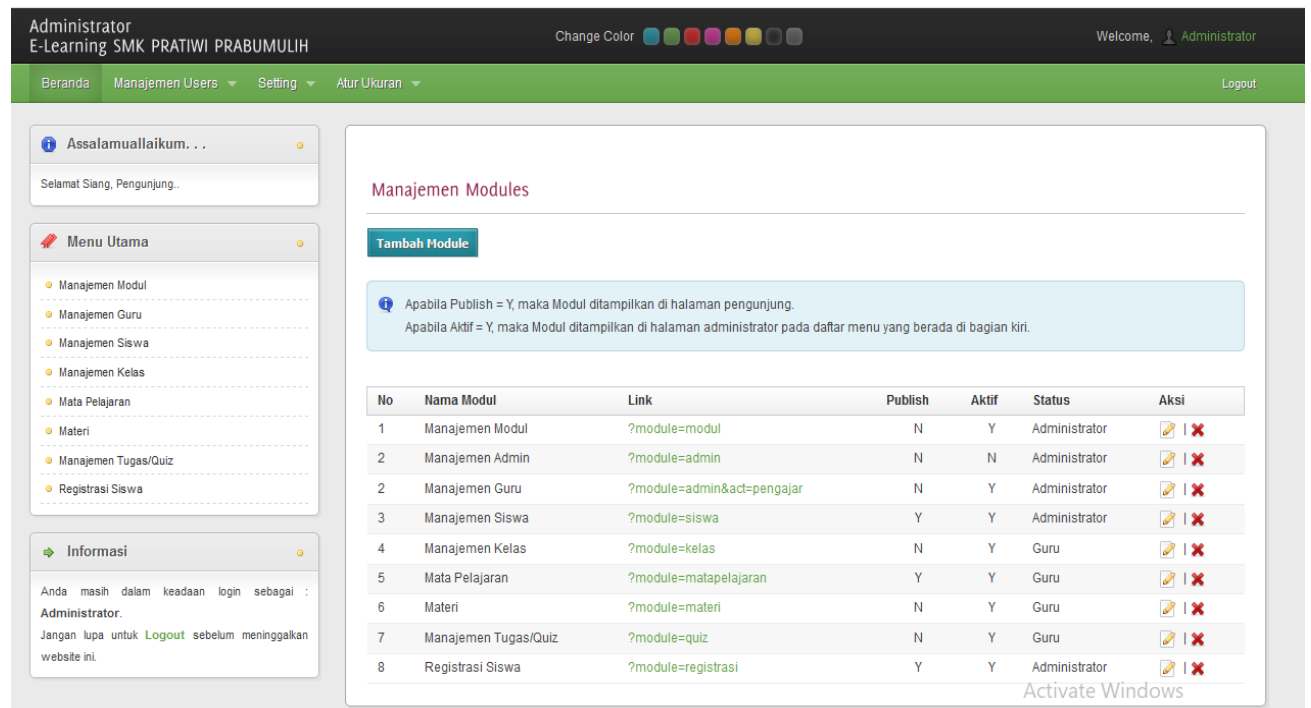

Gambar 4.7 Halaman Manajemen Modul

6. Tampilan Halaman Manajemen Guru

Pada halaman manajemen Guru ini merupakan halaman untuk mengatur, menampilkan, menghapus, mengedit serta menambahkan Guru yang ada pada SMK Pratiwi Prabumulih. Berikut tampilan manajemen Guru:

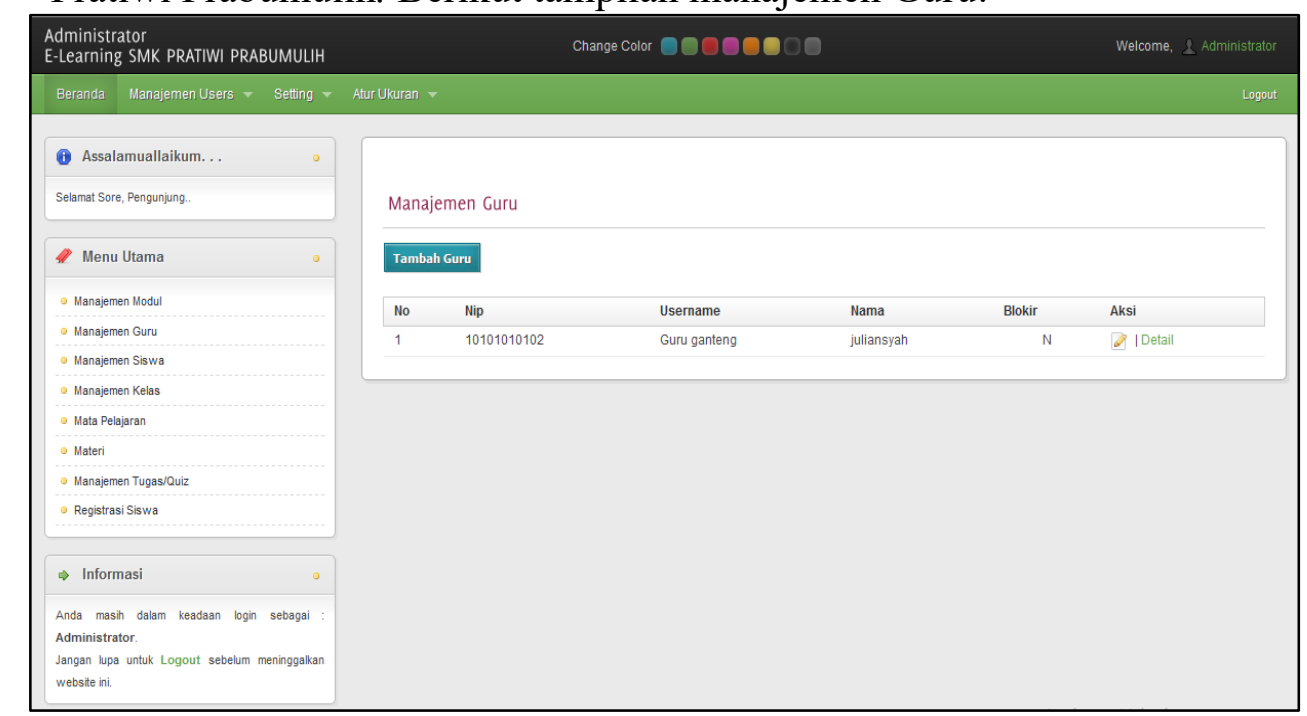

Gambar 4.8 Halaman Manajemen Guru

7. Tampilan Halaman Manajemen Siswa

Pada halaman manajemen Siswa ini merupakan halaman untuk mengatur, menampilkan, menonaktifkan, mengedit serta menambahkan Siswa yang ada pada SMK Pratiwi Prabumulih. Berikut tampilan manajemen Siswa: 


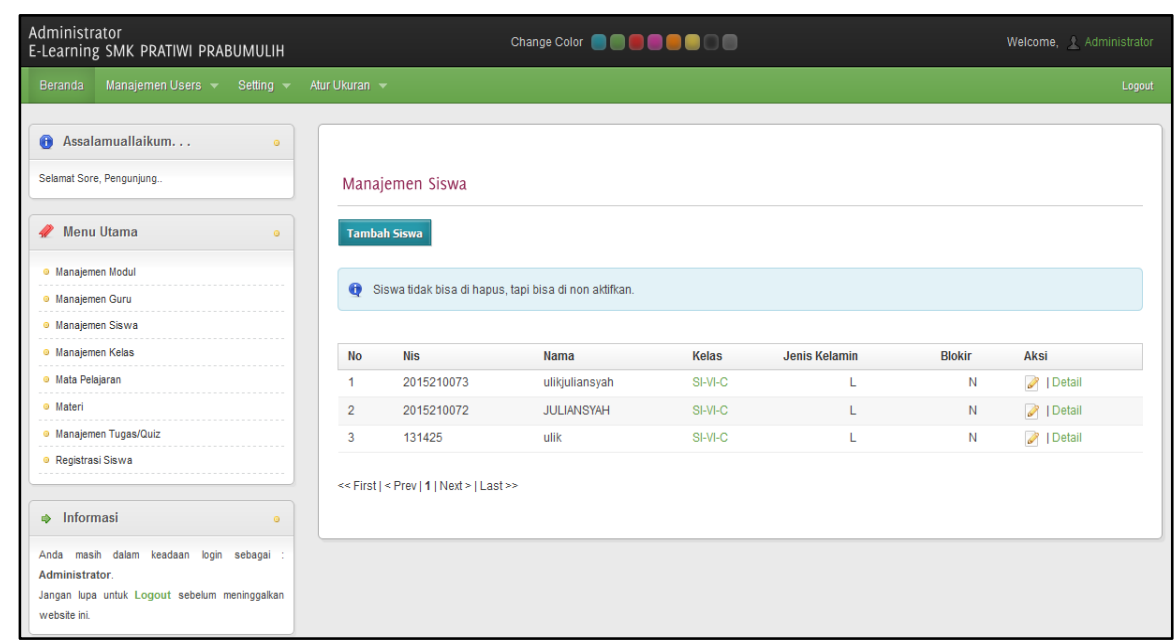

Gambar 4.9 Halaman Manajemen Siswa

8. Tampilan Halaman Manajemen Kelas

Pada halaman manajemen kelas ini merupakan halaman untuk mengatur, menampilkan, menghapus, mengedit serta menambahkan kelas yang ada pada SMK Pratiwi Prabumulih. Berikut tampilan manajemen kelas:

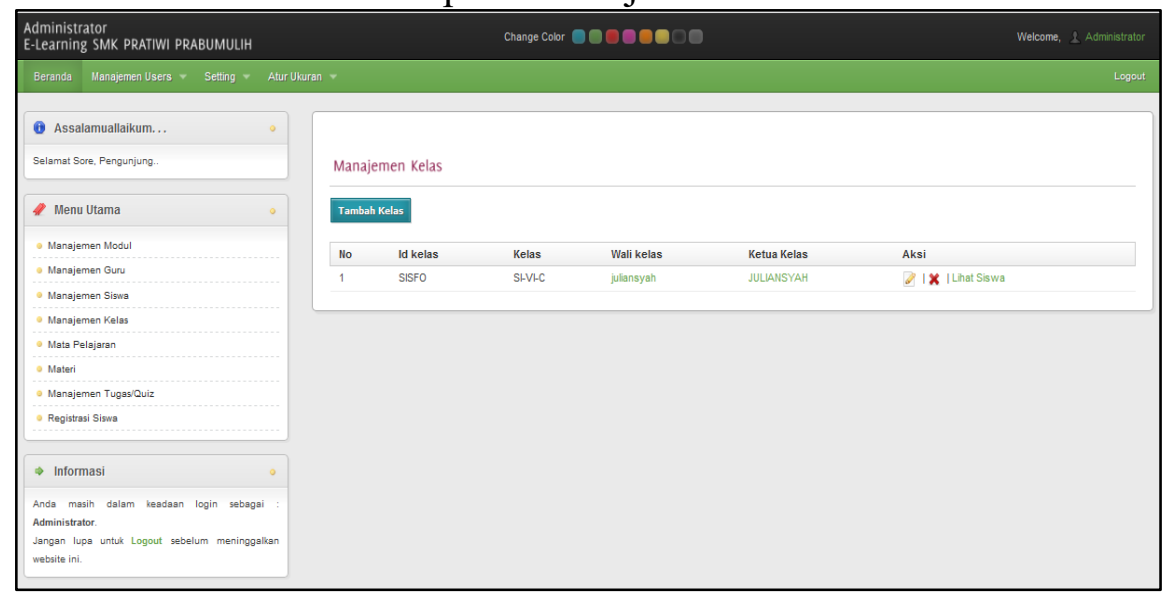

Gambar 4.10 Halaman Manajemen Kelas

9. Tampilan Halaman Manajemen Mata Pelajaran

Pada halaman manajemen mata pelajaran ini merupakan halaman untuk mengatur, menampilkan, menghapus, mengedit serta menambahkan mata pelajaran yang ada pada SMK Pratiwi Prabumulih. Berikut tampilan manajemen mata pelajaran: 


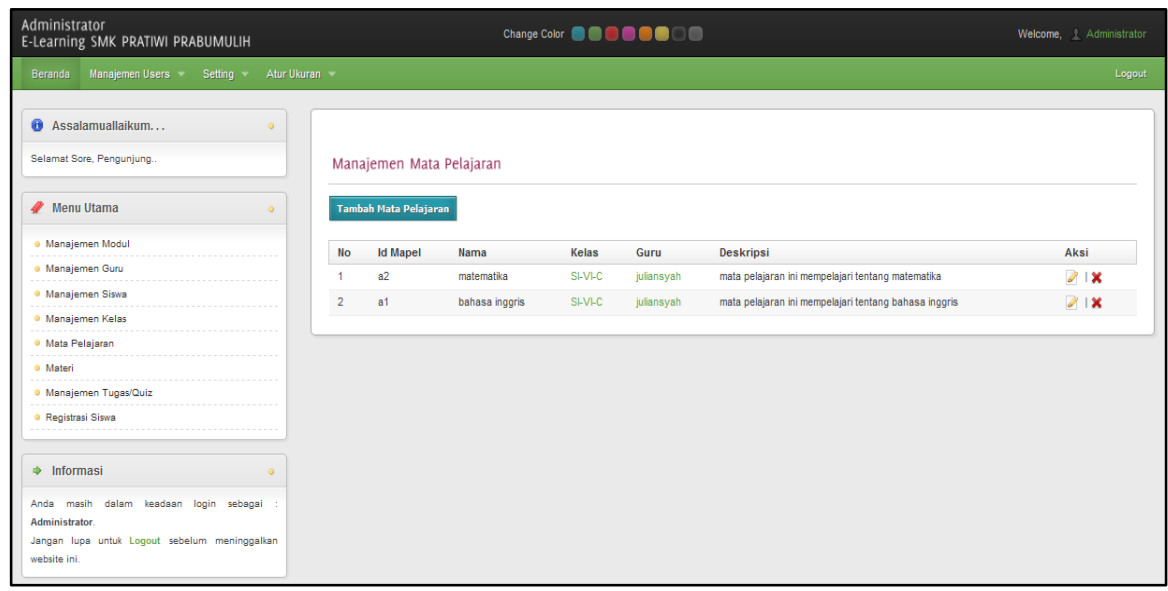

Gambar 4.11 Halaman Manajemen Mata Pelajaran

\subsection{Pengujian Sistem}

Pengujian perangkat lunak ini menggunakan metode pengujian Black Box. Pengujian Black Box berfokus pada persyaratan atau kebutuhan fungsional perangkat lunak yang dibuat. Rencana pengujian Sistem E-Learning SMK Pratiwi Prabumulih menggunakan data uji berupa beberapa data masukan yang diperoleh dari sekolah dan pengisian data dilakukan pada sistem informasi yang telah dibuat, untuk selengkapnya dapat dilihat tabel di bawah ini:

Tabel 4.1 Rencana Pengujian Sistem

\begin{tabular}{|c|c|c|c|}
\hline No & Item Uji & Detail Pengujian & $\begin{array}{c}\text { Jenis } \\
\text { Pengujian }\end{array}$ \\
\hline 1. & Login & Verifikasi Login & Black Box \\
\hline \multirow{3}{*}{2.} & \multirow{3}{*}{ Data Modul } & Tambah Modul & Black Box \\
\hline & & Edit Modul & Black Box \\
\hline & & Hapus Modul & Black Box \\
\hline \multirow{3}{*}{3.} & \multirow{3}{*}{ Data Guru } & Tambah Guru & Black Box \\
\hline & & Edit Guru & Black Box \\
\hline & & Hapus Guru & Black Box \\
\hline \multirow{3}{*}{4.} & \multirow{3}{*}{ Data Siswa } & Tambah Siswa & Black Box \\
\hline & & Edit Siswa & Black Box \\
\hline & & Nonaktifkan Siswa & Black Box \\
\hline & & Tambah Kelas & Black Box \\
\hline
\end{tabular}




\begin{tabular}{|c|c|c|c|}
\hline \multirow[t]{2}{*}{5.} & \multirow[t]{2}{*}{ Data Kelas } & Edit Kelas & Black Box \\
\hline & & Hapus Kelas & Black Box \\
\hline \multirow{3}{*}{6.} & \multirow{3}{*}{ Data Mata Pelajaran } & Tambah Mata Pelajaran & Black Box \\
\hline & & Edit Mata Pelajaran & Black Box \\
\hline & & Hapus Mata Pelajaran & Black Box \\
\hline \multirow{3}{*}{7.} & \multirow{3}{*}{ Data Materi } & Tambah Materi & Black Box \\
\hline & & Edit Materi & Black Box \\
\hline & & Hapus Materi & Black Box \\
\hline \multirow{3}{*}{8.} & \multirow{3}{*}{ Data Tugas/Quiz } & Tambah Tugas/Quiz & Black Box \\
\hline & & Edit Tugas/Quiz & Black Box \\
\hline & & Hapus Tugas/Quiz & Black Box \\
\hline \multirow[t]{2}{*}{9.} & \multirow{2}{*}{$\begin{array}{c}\text { Data Registrasi } \\
\text { Siswa }\end{array}$} & Terima & Black Box \\
\hline & & Hapus & Black Box \\
\hline
\end{tabular}

\subsection{Pengujian Akhir Sistem}

Berdasarkan rencana pengujian yang telah disusun, maka dapat dilakukan pengujian sebagai berikut:

\section{Pengujian Form Login}

Tabel 4.2 Pengujian Form Login

\begin{tabular}{|l|l|l|l|}
\hline \multicolumn{1}{|c|}{ Data Masukkan } & Hasil Yang Diharapkan & Pengamatan & Kesimpulan \\
\hline Username : admin & $\begin{array}{l}\text { Apabila tombol login } \\
\text { diklik, maka akan } \\
\text { diarahkan ke halaman } \\
\text { Password: admin }\end{array}$ & $\begin{array}{l}\text { Data login } \\
\text { sesuai data } \\
\text { masukkan } \\
\text { dan berhasil } \\
\text { login }\end{array}$ & \\
Username : siswa & utama & \\
Password: siswa & & & \\
Username : guru & & & \\
Password: guru & & \\
\hline
\end{tabular}


2. Pengujian Data Tambah

Tabel 4.3 Pengujian Data Tambah

\begin{tabular}{|c|c|c|c|}
\hline Data Masukkan & Hasil Yang Diharapkan & Pengamatan & Kesimpulan \\
\hline $\begin{array}{l}\text { Jenis : user } \\
\text { Profile : }\end{array}$ & $\begin{array}{l}\text { Data tersimpan ke } \\
\text { dalam tabel siswa }\end{array}$ & $\begin{array}{l}\text { Data baru } \\
\text { berhasil } \\
\text { ditambahkan }\end{array}$ & Berhasil \\
\hline $\begin{array}{l}\text { Jenis : Admin } \\
\text { Tambah : Modul }\end{array}$ & $\begin{array}{l}\text { Data tersimpan } \\
\text { dalam tabel modul }\end{array}$ & $\begin{array}{l}\text { Data yang } \\
\text { diinput sesuai } \\
\text { dan tersimpan } \\
\text { ke dalam } \\
\text { database }\end{array}$ & Berhasil \\
\hline $\begin{array}{l}\text { Jenis : Admin } \\
\text { Tambah : Guru }\end{array}$ & $\begin{array}{l}\text { Data tersimpan ke } \\
\text { dalam tabel pengajar }\end{array}$ & $\begin{array}{l}\text { Data yang } \\
\text { diinput sesuai } \\
\text { dan tersimpan } \\
\text { ke dalam } \\
\text { database }\end{array}$ & Berhasil \\
\hline $\begin{array}{l}\text { Jenis : Admin } \\
\text { Tambah : Siswa }\end{array}$ & $\begin{array}{l}\text { Data tersimpan ke } \\
\text { dalam tabel siswa }\end{array}$ & $\begin{array}{l}\text { Data yang } \\
\text { diinput sesuai } \\
\text { dan tersimpan } \\
\text { ke dalam } \\
\text { database }\end{array}$ & Berhasil \\
\hline $\begin{array}{l}\text { Jenis } \\
\text { Admin,Guru } \\
\text { Tambah : Kelas }\end{array}$ & $\begin{array}{l}\text { Data tersimpan ke } \\
\text { dalam tabel kelas }\end{array}$ & $\begin{array}{l}\text { Data yang } \\
\text { diinput sesuai } \\
\text { dan tersimpan } \\
\text { ke dalam } \\
\text { database }\end{array}$ & Berhasil \\
\hline $\begin{array}{l}\text { Jenis } \\
\text { Admin,Guru } \\
\text { Tambah : Mata } \\
\text { Pelajaran }\end{array}$ & $\begin{array}{lcr}\text { Data tersimpan } & \text { ke } \\
\text { dalam tabel mata } \\
\text { pelajaran }\end{array}$ & $\begin{array}{l}\text { Data yang } \\
\text { diinput sesuai } \\
\text { dan tersimpan } \\
\text { ke dalam } \\
\text { database }\end{array}$ & Berhasil \\
\hline $\begin{array}{l}\text { Jenis : } \\
\text { Admin,Guru } \\
\text { Tambah : Materi }\end{array}$ & $\begin{array}{l}\text { Data tersimpan ke } \\
\text { dalam tabel materi }\end{array}$ & $\begin{array}{l}\text { Data yang } \\
\text { diinput sesuai } \\
\text { dan tersimpan } \\
\text { ke dalam } \\
\text { database }\end{array}$ & Berhasil \\
\hline
\end{tabular}




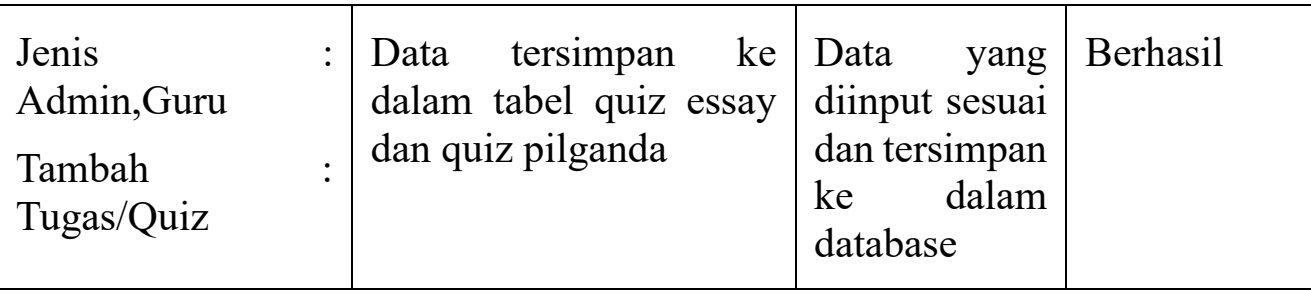

3. Pengujian Data Edit

Tabel 4.4 Pengujian Data Edit

\begin{tabular}{|c|c|c|c|}
\hline Data Edit & Hasil Yang Diharapkan & Pengamatan & Kesimpulan \\
\hline $\begin{array}{l}\text { Jenis : user } \\
\text { Profile : update }\end{array}$ & $\begin{array}{l}\text { Data tersimpan ke } \\
\text { dalam tabel siswa }\end{array}$ & $\begin{array}{l}\text { Data baru } \\
\text { berhasil } \\
\text { ditambahkan }\end{array}$ & Berhasil \\
\hline $\begin{array}{l}\text { Jenis : Admin } \\
\text { Edit : Modul }\end{array}$ & $\begin{array}{lc}\text { Data tersimpan } & \text { ke } \\
\text { dalam tabel modul }\end{array}$ & $\begin{array}{l}\text { Data yang } \\
\text { diinput sesuai } \\
\text { dan tersimpan } \\
\text { ke dalam } \\
\text { database }\end{array}$ & Berhasil \\
\hline $\begin{array}{l}\text { Jenis : Admin } \\
\text { Edit : Guru }\end{array}$ & $\begin{array}{l}\text { Data tersimpan ke } \\
\text { dalam tabel pengajar }\end{array}$ & $\begin{array}{l}\text { Data yang } \\
\text { diinput sesuai } \\
\text { dan tersimpan } \\
\text { ke dalam } \\
\text { database }\end{array}$ & Berhasil \\
\hline $\begin{array}{l}\text { Jenis : Admin } \\
\text { Edit : Siswa }\end{array}$ & $\begin{array}{l}\text { Data tersimpan ke } \\
\text { dalam tabel siswa }\end{array}$ & $\begin{array}{l}\text { Data yang } \\
\text { diinput sesuai } \\
\text { dan tersimpan } \\
\text { ke dalam } \\
\text { database }\end{array}$ & Berhasil \\
\hline $\begin{array}{l}\text { Jenis } \\
\text { Admin,Guru } \\
\text { Edit: Kelas }\end{array}$ & $\begin{array}{l}\text { Data tersimpan ke } \\
\text { dalam tabel kelas }\end{array}$ & $\begin{array}{l}\text { Data yang } \\
\text { diinput sesuai } \\
\text { dan tersimpan } \\
\text { ke dalam } \\
\text { database }\end{array}$ & Berhasil \\
\hline $\begin{array}{l}\text { Jenis } \\
\text { Admin,Guru } \\
\text { Edit: Mata } \\
\text { Pelajaran }\end{array}$ & $\begin{array}{l}\text { Data tersimpan ke } \\
\text { dalam tabel mata } \\
\text { pelajaran }\end{array}$ & $\begin{array}{l}\text { Data yang } \\
\text { diinput sesuai } \\
\text { dan tersimpan } \\
\text { ke dalam } \\
\text { database }\end{array}$ & Berhasil \\
\hline
\end{tabular}




\begin{tabular}{|l|l|l|l|}
\hline $\begin{array}{l}\text { Jenis } \\
\text { Edmin,Guru }\end{array}$ & $\begin{array}{l}\text { Data tersimpan ke } \\
\text { dalam tabel materi }\end{array}$ & $\begin{array}{l}\text { Data yang } \\
\text { diinput sesuai } \\
\text { dan tersimpan } \\
\text { ke dalam } \\
\text { database }\end{array}$ & Berhasil \\
\hline $\begin{array}{l}\text { Jenis } \\
\text { Admin,Guru } \\
\text { Edit: Tugas/Quiz }\end{array}$ & $\begin{array}{l}\text { Data tersimpan ke } \\
\text { dalam tabel quiz essay } \\
\text { dan quiz pilganda }\end{array}$ & $\begin{array}{l}\text { Data yang } \\
\text { diinput sesuai } \\
\text { dan tersimpan } \\
\text { ke dalam } \\
\text { database }\end{array}$ & Berhasil \\
\hline
\end{tabular}

4. Pengujian Data Hapus

Tabel 4.5 Pengujian Data Hapus

\begin{tabular}{|l|l|l|l|}
\hline \multicolumn{1}{|c|}{ Data Hapus } & Hasil Yang Diharapkan & Pengamatan & Kesimpulan \\
\hline $\begin{array}{l}\text { Jenis : user } \\
\text { Profile : update }\end{array}$ & $\begin{array}{l}\text { Data dihapus dari tabel } \\
\text { siswa }\end{array}$ & $\begin{array}{l}\text { Data berhasil } \\
\text { dihapus }\end{array}$ & Berhasil \\
\hline $\begin{array}{l}\text { Jenis : Admin } \\
\text { Hapus : Modul }\end{array}$ & $\begin{array}{l}\text { Data dihapus dari tabel } \\
\text { modul }\end{array}$ & $\begin{array}{l}\text { Data berhasil } \\
\text { dihapus }\end{array}$ & Berhasil \\
\hline $\begin{array}{l}\text { Jenis : Admin } \\
\text { Hapus: Guru }\end{array}$ & $\begin{array}{l}\text { Data dihapus dari tabel } \\
\text { pengajar }\end{array}$ & $\begin{array}{l}\text { Data berhasil } \\
\text { dihapus }\end{array}$ & Berhasil \\
\hline $\begin{array}{l}\text { Jenis : Admin } \\
\text { Hapus : Siswa }\end{array}$ & $\begin{array}{l}\text { Data dinonaktifkan dari } \\
\text { tabel siswa }\end{array}$ & $\begin{array}{l}\text { Data berhasil } \\
\text { di } \\
\text { nonaktifkan }\end{array}$ & Berhasil \\
\hline $\begin{array}{l}\text { Jenis } \\
\text { Admin,Guru } \\
\text { Hapus: Kelas }\end{array}$ & $\begin{array}{l}\text { Data dihapus dari tabel } \\
\text { kelas }\end{array}$ & $\begin{array}{l}\text { Data berhasil } \\
\text { dihapus }\end{array}$ & Berhasil \\
\hline $\begin{array}{l}\text { Jenis } \\
\text { Admin,Guru } \\
\text { Hapus: } \\
\text { Pelajaran }\end{array}$ & $\begin{array}{l}\text { Data dihapus dari mata } \\
\text { pelajaran } \\
\text { materi }\end{array}$ & $\begin{array}{l}\text { Data berhasil } \\
\text { dihapus }\end{array}$ & Berhasil \\
\hline $\begin{array}{l}\text { Jenis } \\
\text { Hapus: Materi }\end{array}$ & $\begin{array}{l}\text { Dahapus berhasil } \\
\text { dihara }\end{array}$ & Berhasil \\
\hline
\end{tabular}




\begin{tabular}{|l|l|l|l|}
\hline $\begin{array}{l}\text { Jenis } \\
\text { Admin,Guru }\end{array}$ & $\begin{array}{l}\text { Data dihapus dari tabel } \\
\text { quiz essay dan quiz } \\
\text { pilganda }\end{array}$ & $\begin{array}{l}\text { Data berhasil } \\
\text { dihapus }\end{array}$ & Berhasil \\
$\begin{array}{l}\text { Hapus: } \\
\text { Tugas/Quiz }\end{array}$ & & \\
\hline
\end{tabular}

\section{Kesimpulan}

Setelah melakukan penelitian dalam kegiatan proses e-learning pada SMK Pratiwi Prabumulih dan berdasarkan hasil dari keseluruhan yang telah di bahas sebelumnya, maka dapat ditarik kesimpulan yang diperoleh, yaitu:

1. Sebelum dibuat aplikasi e-learning, siswa SMK Pratiwi Prabumulih sulit untuk mendapatkan informasi secara langsung mengenai kegiatan belajar mengajar.

2. Sesudah dibuat aplikasi e-learning, siswa SMK Pratiwi Prabumulih mudah untuk mendapatkan informasi secara langsung mengenai kegiatan belajar mengajar, karena ketika guru memberikan informasi tentang kegiatan pembelajaran melalui $e$ learning, maka siswa dapat mengetahui informasi tentang pembelajaran tersebut secara langsung dan dimanapun.

3. Dihasilkan produk aplikasi e-learning dimana e-learning dapat diakses secara online melalui web e-learning SMK Pratiwi Prabumulih dan siswa bisa mendaftar langsung di web yang tersedia di halaman registrasi siswa.

4. Hasil uji coba dengan menggunakan metode black-box menunjukkan bahwa aplikasi E-learning yang di buat tidak terdapat kesalahan navigasi dan access database dan sesuai dengan design yang dirancang.

\section{Referensi}

Abdul Kadir(2013).Pengertian MySQL.Tersedia dalam:Buku Pintar Programer Pemula PHP. Yogyakarta. Mediakom.

Allen, Michael. 2013. Michael Allen's Guide to E-learning. Canada : John Wiley \& Sons.

Antoni, D., \& Akbar, M. (2019). E-supply chain management value concept for the palm oil industry. Jurnal Sistem Informasi, 15(2), 15-29.

Antoni, D., Fikari, D., \& Akbar, M. (2018). The readiness of palm oil industry in enterprise resource planning. Telkomnika, 16(6), 2692-2702.

Antoni, D., Herdiansyah, M. I., Akbar, M., \& Sumitro, A. (2021). Pengembangan Infrastruktur Jaringan Untuk Meningkatkan Pelayanan Publik di Kota Palembang. JURNAL MEDIA INFORMATIKA BUDIDARMA, 5(4), 1652-1659.

Antoni, D., Jie, F., \& Abareshi, A. (2020). Critical factors in information technology capability for enhancing firm's environmental performance: case of Indonesian ICT sector. International Journal of Agile Systems and Management, 13(2), 159-181.

Fauzi, F., Dencik, A. B., \& Asiati, D. I. (2019). Metodologi Penelitian untuk manajemen dan akuntansi. Jakarta: Salemba Empat.

Heny Pratiwi (2016), Buku Ajar SistemPendukung Keputusan. Yogyakarta: Deepublish

Rusman. 2012. Belajar danPembelajaran Berbasis Komputer. Bandung: Alfabeta. 
Rusman., Deni Kurniawan., Cepi Riyana. 2012. Pembelajaran berbasis teknologi informasi dan komunikasi:mengembangkan profesionalitas guru, 2013 akarta: Rajawali Pers

Sutabri Tata, (2016), Sistem Informasi Manajemen, Andi Offset, Yogyakarta. Urva Gellysa

Wena, M. 2010. Strategi pembelajaran inovatif kontemporer (Suatu Tinjauan Konseptual Operasional). Jakarta : Bumi Aksara.

\section{Copyrights}

Copyright for this article is retained by the author(s), with first publication rights granted to the journal.

This is an open-access article distributed under the terms and conditions of the Creative Commons Attribution license (http://creativecommons.org/licenses/by/4.0/) 